\title{
Technical Considerations Influencing Purchase Decisions in the B2B Environment
}

\author{
A. R. Chitra,B. Neeraja,KannigaPrashanth
}

\begin{abstract}
Business organisations consider several technical factors while deciding to purchase their telecom products and services, which can be categorised as brand image, product price, ease of access, point of presence, technical quality, customer service and marketing factors. This study was undertaken to measure the extent to which these factors influence the telecom product purchase decisions of Indian organisations. Organisational buyers preferred, vendors offering products with better operational features and long-term cost reduction programmes, which are easily accessible when required with multiple branches, upgrade their networks and offer better quality and product customisation. Further, while technical considerations indeed affected the purchase decisions, price and point of presence managed to impact decisions independently. Technical considerations interacted with the size of the buying organisations and exerted substantial influence on the purchase decisions and among them, brand image and point of presence exerted a significant impact on purchase decisions along with company size.
\end{abstract}

Keywords - Technical factors, B2B purchase, brand image, customer service, quality, price, access

\section{INTRODUCTION}

The deregulation of the Indian telecommunication industry opened up the gates of the Indian market to the world, which resulted in an influx of local, national and global telecom players (Shah, 2008). As a result, telecom buyers now have a multitude of vendors and a variety of products and services to choose from. However, this has also made buying decisions more complex as the buyers need to make the best and efficient choice from among choices aplenty (Mishra and Rao, 2015). The level of complexity is even higher for organisations that set out to purchase telecom solutions for their use, as they would need to accommodate multiple concerns and viewpoints while deciding to purchase, along with choosing from a diversified market (Shah, 2008). Whom to choose from? A vendor who offers products of good quality at a reasonable price? Or from a globally reputed brand? Would it be better to buy from a vendor who is easily accessible or is it wise to pick a vendor with smart marketing tactics and great after-purchase service? These are some of the questions that the organisational buyers need to address as they decide to source telecommunication products (Chowdary, 1998; IBEF, 2017). While these questions are important, not only for the buyers, but for the vendors as well, as they questions

Revised Manuscript Received on April 12, 2019.

A. R. Chitra, Research Scholar, Faculty of Management Studies, Dr. M. G. R. Educational and Research Institute, Maduravoyal, Chennai, T.N, India. (E-mail:ar_chitra@yahoo.com)

Dr. B. Neeraja, Professor, Faculty of Management Studies, Dr. M. G. R. Educational and Research Institute, Maduravoyal, Chennai,T.N, India. . E-mail:neerajavijay93@gmail.com)

Dr. KannigaPrashanth, Facult y- Business Studies, Shinas College of Technology, Sultanate of Oman, (E-mail:profkanniga@yahoo. com) reflect the trend and expectations of the market and catering to the same could help them do better business (Shah, 2008). Thus, the organisational buying behaviour in a telecom product parlance is subject to a complex set of considerations and objectives.

Organizational buying behaviour pertains to the systems and processes followed by organisations while purchasing goods and services from other organisations or vendors (Nair, Jayaram and Das, 2015). Organisational buying is essentially a Business-to-Business (B2B) construct, i.e., here both buyers and sellers are organisations or businesses and not individual end-users, i.e., one business buys from another business for its own use (Kahraman, Cebeci and Ulukan, 2003). B2B purchase is quite different from individual purchase in the sense that is considerably complex and long drawn than the latter. Organisational purchase can be safely referred to as a sum total of the deliberations and decisions made my multiple departments and multiple stakeholders, considering the short and long term objectives of the purchasing firm (Jobber, 2001).

Among the various considerations that come into play when organisations decide to purchase, technical attributes of the product are paramount (Pride and Ferrell, 2009). Technical considerations are those attributes, which are directly associated with the product or service being purchased and its vendor, and it can include purely tangible aspects, such as product specification, price and quality or intangible aspects, such as the brand, brand image or loyalty (Kotler and Armstrong, 2010). In a way, technical considerations serve as the basic factors, which help organisations in deciding to purchase from a vendor and this makes them the most important drivers of organisational buying behaviour (Luthra et al. , 2017). While the each firm might have different expectations pertaining to the products they would want to buy, they can be broadly summarised as the need for affordability, accessibility, quality, global and local reputation, marketing efforts, availability of afterpurchase care and a reliable image (Sarin, 2014; Krause, 2007).

While reasonable prices and good quality continue to be the primary concerns of a buying organisation, there are other technical aspects, which need to be focused during purchase. (Koufteros, Vickery and Droge, 2012) Easy accessibility information pertaining to the price, afterpurchase care, installation support and product range etc. is one such technical attribute which organisations consider while deciding to purchase, as it would help not only help them make an informed choice, but would also make it 
simpler to reach out to the vendor as and when issues arise (Jobber, 2007; Krause, 2007). Thus, easily accessible vendors gain a convenient edge over the inaccessible ones. (IBM, 2015). The quality of customer services is another technical aspect which deserves a mention, as availability of consistent and reliable after-sales service support would imply that the buyers need not worry about maintenance of the products, which would ease them off a great deal of pressure over the long run (Jobber, 2007).

As mentioned earlier, a majority of organisational buyers do not wish to compromise with regard to the quality of the product and services they procure, and would be willing to overrule price and other considerations for good quality (Chiu, Lee and Kao, 2015). As the pressure to perform efficiently began to mount, many firms, which formerly made their purchase decisions based on purchase price, shifted their focus to better quality (Dean and Terziovski, 2001). However, the emphasis on product quality did not essentially take the organisational buyers' focus away from the product price. From a B2B purchase perspective, product price does not mean simply the price paid at purchase, but also includes what the buyers would incur on the product over its lifetime (Jobber, 2007). For instance, the price of particular machinery includes not only its purchase price, but also the expenses that are incurred for its maintenance and upkeep for as long as it remains in use. That apart, product price also includes how much of the operating costs a buying firm would save by purchasing that particular product (Pride and Ferrell, 2009). Therefore, price would certainly be one of the important technical considerations of $\mathrm{B} 2 \mathrm{~B}$ purchase decisions.

As marketing initiatives and promotional strategies gain prominence, a number of organisational buyers have begun warming up to different marketing promotional strategies of the vendors (Ballantyne and Aitken, 2007). Marketing efforts and promotional initiatives not only help them expand their sales in the market, but also help the buyers decide whether or not they want to buy from a particular seller, by weighing the pros and cons of the same (Kotler and Pfoertsch, 2007). Further, promotional efforts also reflect what the vendors endorse, whether they value long term business relationships, whether or not they believe in creating value and so on. As organisational buying would be recurrent and the sellers and buyers would collaborate over longer periods, firms consider the aforementioned factors matters while deciding to purchase (Brown, Bellenger and Johnston, 2007).

Point of presence of a supplier, i.e., whether or not the vendor has multiple branches and/or global presence, is also one of the critical factors that crucial factor affecting competitive positioning of the company (Trent and Monczka, 2003). In an increasingly liberalised market, every firm aspires to have a global presence, as it not only helps them aim for a bigger customer base, but also implies that their products of global standards (Eid, Trueman and Ahmed, 2002). At the same time, vendors with a large network of branches is also seen as a better suppliers as they are perceived as possessing better market knowledge and experience (Rahim, 2013). With this backdrop, point of presence of the vendor is also considered one of the important technical factors that organisational buyers

consider while making purchase decisions. Apart from the aforementioned tangible attributes, organisational purchase decisions are also influenced by how the purchase decision makers firm perceive the supplier brand, i.e., brand image (Lehmann and O'shaughnessy, 1974; Shaw, Giglierano and Kallis, 1989), based on their past purchase experiences from the vendor and their opinions about the brand.

Therefore, brand image, ease of access, product price, quality, point of presence, marketing and customer care broadly constitute the technical attributes that are considered while making B2B purchase decisions; however, every organisational buyer might attach different levels of importance to each of these attributes based on their expectations and perceptions (Mudambi, 2002; Morgan, Deeter-Schmelz and Moberg, 2007). Thus, each organisational buyer from different industries can have different views about the prominence of each of the technical attribute, which makes it necessary to recognise the factors, which are considered the most while making a purchase decision, from an individual industry perspective.

In connection with the above, the present paper is an attempt to understand what matters the most to purchasing organisations, while deciding to purchase telecom products and services from other vendors. Such an understanding of the organisational purchase behaviour is necessary in the sense that it helps buyers make an effective purchase decision by giving adequate importance to each attribute and enables the vendors to strategise their sales by catering to consumer expectations. With the above backdrop, the present study was undertaken in order to

1) Assess the organisational buyers' perception about the technical considerations of purchase decision, and

2) Investigate the extent to which technical considerations can impact B2B purchase decisions.

\section{LITERATURE REVIEW}

The fact that technical attributes of telecom products are paramount in the organisational purchase decisions is undisputable, as it in turn has a bearing upon how the buying organisations perform; however, marketing constructs, such as brand image and loyalty also impact buying decisions. This fact was reiterated by Mudambi (2002) in a model, wherein it was posited that the technical attributes of products, such as price and specifications shape purchase decisions along with support and assistance services. Besides, intangible constructs, such as the buyers' perception of the particular brand image also played an important role in purchases decisions. In a similar study, the significance of branding was emphasised by Brown, Bellenger and Johnston (2007) in both B2B and B2C contexts. According to the authors, purchasing from brands with a robust image, results in lower risks emanating out of wrong decisions. Similarly, it was also found that buying products of better technical quality also reduces risk on the part of organisational buyers.

In another study emphasising brand image, Morgan, Deeter-Schmelz and Moberg (2007) proposed a model to 
measure the brand image pertaining to services, while emphasising its intangibility. Through this model, the authors suggested that the strength of a supplier brand has a strong influence on how customers evaluate the same while deciding to purchase. Similarly, the importance of branding was also reiterated by Sarin (2014) through a model measuring the prominence of branding in organisational decisions. According to the author, brand image was given utmost importance while making organisational purchase decisions except in cases where the buyers are well informed about the product and do not attach much value to the brand image. Further, the significance of technical considerations of purchase decisions, were dealt with in detail in a model Mudambi, Doyle and Wong (1997). According to the model, product performance, i.e., quality, performance, support and distribution services of the vendors add value to their brand value and on the basis of this value, the clients decide whether they want to purchase from those suppliers.

A conceptual discourse or organisational decision-making was offered Bolton, Lemon and Verhoef (2008) in their model on industrial decision making, wherein they depicted the factors considered while evaluating a vendor for purchase. According to the authors, purchase price, service quality and the clients' perceptions regarding the vendors' service based on past experiences, by and large direct organisational purchase decisions. In a similar study, Luthra, Govindan, Kannan, Mangla and Garg (2017) elaborated upon vendor selection process, in the context of the automobile industry and identified five factors that are considered while evaluating a prospective vendor, namely, environmental costs, product quality, product price, safety and environmental competency, wherein the importance attached to price and quality are evident. In a similar study on supplier selection criteria, Chiu, Lee and Kao (2015) found five categories of criteria what are paramount to a purchase decision process, namely, quality, level of service, relationship with customers, organizational ability and product price. In a similar study, Nurmi (2012) found that the quality of the product in relation with the price paid influenced the organisational buying process considerably and that customisation of the product according to the buyers' needs and simpler applicability were important.

The prominence of product quality for a purchasing organisation was explained by Azar, Kahnali and Taghavi (2010) who emphasized the importance of considering quality as a criterion for selection of suppliers in the industrial market. In a similar study focusing on the role of product quality in purchase decisions, Bals, Hartmann and Ritter (2009) found three different quality attributes of products which the clients emphasize while making a purchase, namely, how the purchase improves their output quality; how does the purchase effect their sales targets and how does it improve their customer. Similarly, Lai, Cheng and Yeung (2004) discussed the importance of product quality in purchase decisions and the role it plays in fostering a stable B2B buyer-seller relationships. It was found that buyers transact often with sellers providing better quality products, which eventually results in stable business relationships. The prominence of product quality was elaborated upon by Kuei, Madu and Lin (2001) who investigated the quality management practices in supply chains and found that the supplier firms' tendency to provide better quality products usually worked in favour of them as they fetched them more business.

In another study on the importance of brand image, Haubmann (2016) examined how brand image along with brand performance, attachment, reputation, credibility, reputation, trust and feelings impacted the buyers' perceptions in the B2B market. The findings implied that how organisational buyers feel about a particular brand affects the B2B buying behaviour significantly. The need to take up branding initiatives was justified by Travis (2015) in the context of the Finnish B2B market. According to the author, promoting a positive image of the firm using branding and visual marketing strategies is necessary on the part of the vendors to gain good customers. Similarly, Gomes, Fernandes and Brandão (2014) investigated how branding initiatives can impact purchase decisions. The findings implied that vendors need to improve carve out an impressive brand reputation for themselves as buying organisations attach significant value to the same while deciding to purchase.

Significant impact of branding on B2B purchase decisions was recorded by Gartnell, Freij and Svensson (2013) and Sarin (2014), both of whom found that brand image exerted a significant influence on the purchase decisions in the B2B market. Similarly, Walley et al. (2007) found that among the five governing factors of organisational purchase decisions, namely, price, quality, brand image, proximity of the dealer and previous experiences with the dealer, brand image influenced the purchase decisions the most. In a similar study, Blomback and Axelsson (2007) examined the role of brand image in vendor selection. The results implied that as buyers link brand image trust, competence, timely delivery, quality, brand image is paramount in vendor selection.

Bendixen, Bukasa and Abratt (2003) examined the impact of branding on the consumers' willingness to pay for the products try new ones. According to the authors, buyers do not mind paying higher prices for established brands and don not mind trying other products of the same brand. Ebitu, Essien and Basil (2012) undertook an investigation of the factors affecting vendor selection and found that the differences in price and quality of products impacted their probability of being favoured as vendors; however, most purchase decisions were made on the basis of product price. Similar observations were made by Mwikali and Kavale (2012) who found that found cost of product is the most important criteria considered while selecting a vendor. However, contrasting evidences were provided by Lambert, Adams and Emmelhainz (1997) who found that rather than the product price, factors, like quality and timely delivery were considered important for vendor selection. According to the findings of the study, price was the least significant in the context of buying decisions. Similar observations were made by Abratt (1986) who found that service quality was the most important factor considered while deciding to purchase rather than product price. 
The significance of ease of access and point of presence in purchase decision making was reiterated by $\mathrm{Ho}, \mathrm{Xu}$ and Dey (2010) who observed that while quality was considered most important while deciding to purchase, other factors, such as geographical location of the vendor and proximity to the buyer were also considered with caution while making purchase decisions. In a similar study, Ng (2010) found that in the agriculture sector of Taiwan, geographical location of the vendor was given importance while making purchase decisions, along with the vendors' financial standing and service quality. Adverting to how a global presence of the vending firms can help buyers gain a competitive edge in the market, Trent and Monczka (2003) argued that firms which source products from global markets tend to perform better financially. Therefore, the authors opined that buying organisations tend to opt for vendors with global presence in anticipation of world-class quality products.

An elaborate review of past literature pertaining to the technical factors that hold sway over organisational purchase decisions in a B2B market context uncovered in depth research studies that have been undertaken so far. A majority of the studies focused on quality, price and branding as the important determinants of organisational purchase decisions. However, there was a dearth of studies, which deal with the role played by other factors, such as point of presence and marketing attributes of the vendor. Further, the studies delving into organisational purchase decisions in the Indian B2B market are very few.

The following alternative research hypotheses were framed based on the learnings from the literary review:

Hypothesis $\mathbf{1}_{\mathrm{A}}$ : Technical considerations associated with the telecom product vendors impact the organisational buyers' purchase decision.

Hypothesis $\mathbf{2}_{\mathrm{A}}$ : The technical attributes of telecom products and solutions exert a significant impact on $\mathrm{B} 2 \mathrm{~B}$ purchase decisions in collaboration with the size of the buying organization.

\section{METHODOLOGY}

The study employed a pragmatic research philosophy and a convergent parallel and interpretive design. The study, which is inductive in nature, used a mixed-method strategy, i.e., both quantitative and qualitative approaches were used. While the qualitative data was collected using personal interviews, quantitative data were collected using structured questionnaires. The study was conducted across Indian cities, namely Chennai, Bengaluru, Hyderabad, Pune, Mumbai and New Delhi, and it included both vendors and organisational buyers of telecom products and the data was collected over a span of seven months from November 2018 to May 2019. A pilot study was conducted about six months before the actual data collection and the research instruments were fine-tuned by eliminating sensitive, redundant and irrelevant questions. The reliability of the research instruments was ascertained using Cronbach's Alpha and validated using Factor Analysis.

The fine-tuned questionnaires were then administered to 250 individuals, employed in the middle and top management levels of buying organisations, which are in existence for at least two years, with offices in at least four locations and using telecom services for at least six months.
Further, 10 vendors functioning from at least last two years, catering to at least five organisational buyers, either presently or in the past were interviewed personally. Further, various online databases and websites, along with hardcopy publications, like thesis, books, journal articles were consulted for the secondary data. The data so collected was then subjected to statistical analysis using the Statistical Package for Social Sciences (SPSS) version 24, where descriptive statistics, such as mean and standard deviation and statistical methods, such as regression and univariate analysis were employed to test the research hypotheses.

\section{RESULTS AND DISCUSSION}

The present section describes the results of data analysis, which are presented in the form of tables and charts, wherever appropriate. The section begins with a discussion of reliability and validity analysis of the research instruments, followed by a description of the organisational buyers' perceptions regarding technical factors considered while making purchase decisions. This is followed by testing of the research hypotheses using regression and univariate analysis.

\section{1. Reliability Statistics}

Reliability analysis was carried out to assess the extent to which the questionnaire used for the study was 'reliable', i.e., how far was it able to produce consistent outcomes on using repeatedly. From the findings presented in Table 1, it can be seen that for all the scales pertaining to the technical and market factors, Cronbach's alpha values in the range of 0. 6-0. 9 were obtained and this implies that the questionnaire is reliable and would yield similar outcomes on recurrent use. The highest Cronbach's alpha value was recorded for technical quality of the product and the vendor (12 items), i.e., 0.942 followed by 0.940 for ease of access of the vendor ( 8 items) and 0.783 for customer service and marketing ( 4 items). This was followed by 0.684 for point of presence of the supplier ( 4 items), 0.683 for product price ( 7 items) and 0.642 for brand image ( 5 items). These findings confirmed the reliability of the questionnaire used for the study.

Table 1.Reliability statistics for sub factors of technical and market factors, social capital factors and level of involvement

\begin{tabular}{lcc}
\hline \multicolumn{1}{c}{$\begin{array}{c}\text { Sub Constructs of Technical } \\
\text { Considerations }\end{array}$} & $\begin{array}{c}\text { Cronbach's } \\
\text { Alpha }\end{array}$ & N \\
\hline Brand Image & 0.645 & 5 \\
Point of presence of supplier & 0.684 & 4 \\
Pricing & 0.683 & 7 \\
Ease of Access & 0.940 & 8 \\
Technical quality attributes of the & 0.942 & 12 \\
service provider & & \\
Customer service and marketing & 0.783 & 4 \\
attributes & & \\
\hline
\end{tabular}




\section{2. Validity Testing}

The validity of a research tool implies the extent to which the particular tool is able to measure what it is supposed to measure. Simply put, a questionnaire with decent validity will be able to measure the variables of the study quite effectively. The findings of validity testing conducted in the context of the present study are provided in Tables 2 and 3. A KMO and Bartlett's Test of Sphericity was performed to investigate whether the sample selected for study was adequate to measure the study variables and construct. A KMO value of 0.860 and a Bartlett's Test of sphericity value of 0.000 were obtained, which confirmed that the sample was adequate to measure the research constructs.

Table 2.KMO and Bartlett's Test for Technical Factors Affecting Purchase Decisions

\begin{tabular}{llc}
\hline $\begin{array}{l}\text { Kaiser-Meyer-Olkin Measure of Sampling } \\
\text { Adequacy. }\end{array}$ & 0.860 \\
\hline Bartlett's Test of Sphericity & $\begin{array}{l}\text { Approx. } \\
\text { Chi-Square }\end{array}$ & 10298.567 \\
& $\begin{array}{l}\text { Df } \\
\text { Sig. }\end{array}$ & 780 \\
& & 0.000 \\
\hline
\end{tabular}

Exploratory factor analysis was carried out on the technical considerations of purchase decision and six factors were identified, namely, brand image, point of presence of the vendor, ease of access, product price, technical quality of the product and the vendor, customer service and marketing attributes. Factor loading around the value of ' 1 ' implies a strong influence of the factors and factor near to 0 denotes a weaker impact. It is clear from the Table 3 , that the technical quality attributes of the service provider is the most prominent factor as it explained around $41.94 \%$ of the variation in B2B purchase decisions and the rest had a much lesser impact. Among the remaining factors, the ease of access of the vendors accounted for about $7.506 \%$ variation in purchase decision followed by customer service and marketing attributes (5. 034\%), brand image (4. 498\%), product price $(3.853 \%)$, and point of presence of the supplier (3. 440\%), implying that their role in explaining variation in purchase decisions is quite limited. Nonetheless, the factor loadings of all the factors under each construct of the study had a value of more than 0.5 , which implied that all the sub-factors of technical considerations indeed significant for B2B purchase decision.

Table 3.Exploratory Factor Analysis for Technical Considerations

\begin{tabular}{|c|c|c|c|}
\hline Factors & $\begin{array}{c}\text { Factor } \\
\text { Loading }\end{array}$ & $\begin{array}{c}\% \\
\text { Variance } \\
\end{array}$ & $\begin{array}{c}\text { Cumulative } \\
\%\end{array}$ \\
\hline Technical quality attributes of the service provider & - & 41.943 & 41.943 \\
\hline $\begin{array}{l}\text { I study the balance sheet of the vendor and select a profitable } \\
\text { vendor }\end{array}$ & 0.526 & & \\
\hline My purchase negotiations are largely based on the aspect of quality & 0.694 & & \\
\hline $\begin{array}{l}\text { I prefer suppliers who can design their products according to our } \\
\text { requirements and specifications }\end{array}$ & 0.748 & & \\
\hline $\begin{array}{l}\text { I prefer suppliers who upgrade their network well ahead of } \\
\text { customer needs }\end{array}$ & 0.719 & & \\
\hline I prefer suppliers who offer a short network recovery time & 0.809 & & \\
\hline I prefer suppliers who can offer faster network upgrade ability & 0.894 & & \\
\hline I prefer suppliers who use latest technology and keep updating & 0.839 & & \\
\hline $\begin{array}{l}\text { I prefer supplier who has real-time capability for providing network } \\
\text { services spanning organizational and geographic boundaries }\end{array}$ & 0.829 & & \\
\hline I prefer suppliers offering complete end-to-end solution on its own & 0.659 & & \\
\hline $\begin{array}{l}\text { I prefer suppliers who adhere to the service level } 4 \text { ments regarding } \\
\text { the up time and response time }\end{array}$ & 0.873 & & \\
\hline $\begin{array}{l}\text { Supplier's preparedness to meet our demand on short notice plays } \\
\text { and important role in buying decision }\end{array}$ & 0.680 & & \\
\hline $\begin{array}{l}\text { I prefer suppliers offering products with least perish ability, i.e., } \\
\text { longer life of the products and services }\end{array}$ & 0.799 & & \\
\hline Ease of Access & - & 7.506 & 49.448 \\
\hline I prefer suppliers who are easily accessible logistically & 0.502 & & \\
\hline I prefer suppliers who support their clients in the time of need & 0.817 & & \\
\hline $\begin{array}{l}\text { I prefer suppliers who are willing to cooperate beyond contractual } \\
\text { provisions }\end{array}$ & 0.571 & & \\
\hline I prefer suppliers who provide value-added services. & 0.787 & & \\
\hline I prefer reliable and efficient suppliers & 0.826 & & \\
\hline I prefer suppliers who can track and coordinate online purchases & 0.720 & & \\
\hline
\end{tabular}




\begin{tabular}{|c|c|c|c|}
\hline $\begin{array}{l}\text { I prefer suppliers whose personnel are easily accessible in times of } \\
\text { need }\end{array}$ & 0.707 & & \\
\hline $\begin{array}{l}\text { I appreciate easy access to the top management of suppliers in } \\
\text { cases of disputes or making strategic purchase plans }\end{array}$ & 0.780 & & \\
\hline Customer service and marketing attributes & - & 5.034 & 54. 482 \\
\hline $\begin{array}{l}\text { I prefer suppliers who uses advertisements and promotions to } \\
\text { sensitize and attract customers }\end{array}$ & 0.618 & & \\
\hline $\begin{array}{l}\text { I decide in favour of suppliers provider who strive to improve } \\
\text { customer satisfaction through value-added services }\end{array}$ & 0.710 & & \\
\hline Suppliers should offer better quality and customization services & 0.837 & & \\
\hline $\begin{array}{l}\text { In order to deal with a supplier, I need to be confident of their } \\
\text { capability to deliver better product and service }\end{array}$ & 0.739 & & \\
\hline Brand Image & - & 4.498 & 58.980 \\
\hline $\begin{array}{l}\text { I favour the few supplier brands I am familiar with while making } \\
\text { purchase decision }\end{array}$ & 0.802 & & \\
\hline $\begin{array}{l}\text { My commitment to specific brands makes the purchase decision } \\
\text { easy. }\end{array}$ & 0.598 & & \\
\hline I always rely on brand information for making purchase decisions. & 0.802 & & \\
\hline Product Price & - & 3.853 & 62.833 \\
\hline I prefer a supplier offering long-term joint cost-reduction programs & 0.646 & & \\
\hline I prefer a supplier offering an efficient process integration & 0.521 & & \\
\hline I may change my telecom operator in cases of increased prices & 0.589 & & \\
\hline Availability of reasonable offers encourage me to avail the service & 0.762 & & \\
\hline $\begin{array}{l}\text { Availability of attractive packages including customized solution, } \\
\text { longer credit, encourage me to avail the service }\end{array}$ & 0.763 & & \\
\hline Point of presence of supplier & - & 3.440 & 66. 273 \\
\hline My supplier has presence in multiple locations & 0.634 & & \\
\hline My supplier has a global presence & 0.853 & & \\
\hline I prefer a supplier with a global presence than only local operation & 0.843 & & \\
\hline
\end{tabular}

\section{3. Respondent Perceptions on the Technical Considerations of Purchase Decision}

Descriptive statistical analysis was performed to measure the extent to which the respondents of the study, i.e., the organisational buyers perceived each technical attribute's role in B2B purchase decisions and the findings of the same are discussed in this section.

\section{3. 1. Brand Image}

Descriptive statistics pertaining to the respondents' perception regarding the significance of brand image in purchase decisions of buying organisations are presented in Table 4. At the outset, the respondents were found to attach significant importance to the operational features of the telecom products $(M=3$. 712) while making purchase decisions, i.e., most respondents agreed that they are influenced by the operational features of the products while considering them for a purchase. Further, the respondents had a neutral response with regard to the role of brand loyalty ( $M=3$. 197), familiarity with the vendor $(M=3.212)$, commitment to brands $(M=2.848)$ and brand information in the purchase decision (3. 114). Therefore, brand image did not seem to influence the purchase decision of the organisational buyers, as they were more concerned about the operational features of the products, rather than about what they think about the brand to which they belong.
Table 4.Descriptive Statistics for Brand Image

\begin{tabular}{lcc}
\hline \multicolumn{1}{c}{ Questions } & Mean & $\begin{array}{c}\text { Std. } \\
\text { Deviation }\end{array}$ \\
\hline $\begin{array}{l}\text { Influenced by brand loyalty aspect } \\
\text { while making a purchase decision. }\end{array}$ & 3.197 & 0.998 \\
$\begin{array}{l}\text { Favouring familiar vendor brands } \\
\text { while making purchase decisions }\end{array}$ & 3.212 & 0.979 \\
$\begin{array}{l}\text { Influenced by operational features } \\
\text { while making purchase decisions. }\end{array}$ & 3.712 & 1.072 \\
$\begin{array}{l}\text { Commitment to specific brands } \\
\text { eases the purchase decision. }\end{array}$ & 2.848 & 1.134 \\
$\begin{array}{l}\text { Dependence on brand information } \\
\text { while deciding to purchase. }\end{array}$ & 3.114 & 1.066 \\
\hline
\end{tabular}

\section{3. 2. Product Price}

The descriptive statistics pertaining to the respondents' perceptions regarding the role of product price in purchase decisions are presented in Table 5. Most respondents preferred vendors who offer long term cost reduction programmes $(\mathrm{M}=3$. 818), followed by those offering an efficient process integration $(\mathrm{M}=3$. 795), which again helped reduce overheads and vendors who bundle all the related hardware as a part of their service $(\mathrm{M}=3$. 705) at the same prize. Similarly, most respondents also seemed to favour vendors who offer attractive 
packages along with their services, such as customised solutions, longer credit period, etc. at the same price $(M=3.667)$ and a good number them felt that adopting a service contract as part of the pricing strategy $(M=3.515)$ would improve the chances of such products being purchased. However, the respondents were neutral regarding the possibility of changing a supplier due to price rise $(M=3$. 326) and favouring vendors who give reasonable offers $(\mathrm{M}=3.409)$.

The findings of the descriptive analysis indicate that organisational buyers do not attach a lot of value to lower purchase prices or purchase offers, yet favoured vendors who help them reduce long-term costs. Further, the buyers like to purchase from vendors who provide integrated solutions or all product related services and accessories together, and liked clarity with regard to pricing. Therefore, while purchase price was not of great importance to the buyers, reduction in maintenance expenses and efficient processes were indeed paramount while deciding to purchase.

Table 5.Descriptive statistics for pricing

\begin{tabular}{lcc}
\hline \multicolumn{1}{c}{ Questions } & Mean & $\begin{array}{c}\text { Std. } \\
\text { Deviation }\end{array}$ \\
\hline $\begin{array}{l}\text { Prefer vendors offering long-term } \\
\text { cost-reduction programs }\end{array}$ & 3.818 & 1.088 \\
$\begin{array}{l}\text { Prefer a supplier offering an } \\
\text { efficient process integration }\end{array}$ & 3.795 & 1.155 \\
$\begin{array}{l}\text { Price rise could result in changing } \\
\text { the vendor }\end{array}$ & 3.326 & 0.885 \\
$\begin{array}{l}\text { Availability of reasonable offers } \\
\text { favours purchase decision }\end{array}$ & 3.409 & 0.897 \\
$\begin{array}{l}\text { Availability of attractive packages } \\
\text { including customized solution, }\end{array}$ & 3.667 & 0.968 \\
$\begin{array}{l}\text { longer credit, favours purchase } \\
\text { decision }\end{array}$ & & \\
$\begin{array}{l}\text { Prefer suppliers adopting aservice } \\
\text { contract as a pricing strategy }\end{array}$ & 3.515 & 0.785 \\
$\begin{array}{l}\text { Prefer suppliers who bundle } \\
\text { required hardware as part of their } \\
\text { service }\end{array}$ & 3.705 & 0.852 \\
\hline
\end{tabular}

\section{3. 3. Ease of Access}

Descriptive statistics pertaining to the respondents' perceptions regarding the role of ease of accessing the vendor in the purchase decision process are presented in Table 6. At the outset, organisational buyers were found to attach significant importance to most of the aspects of easy vendor accessibility, as they agreed with most of the questions pertaining to ease of access of vendors.

At the outset, buyers were found to favour vendors whose staff are easily available for help when required $(\mathrm{M}=3$. 727), while making purchase decisions and preferred suppliers who they can easily reach out logistically $(M=3$. 644), i.e., located nearbyor whose stores can be visited frequently and supplier organisations where top management is easily accessible when there are disputes $(M=3$. 644). Further, respondents also favoured vendors providing value added services $(M=3$. 629) and those who are reliable and efficient $(M=3.629)$, equally.

Organisational buyers were also found to like it when vendors offer support to their clients in times of need $(M=3$. 591), i.e., those who were interested in client welfare apart from their profits and they also favoured vendors who have facilities to track and coordinate online product purchases ( $M=3$. 508). However, the buyers' responses were neutral when they were asked whether they favoured vendors who cooperated beyond contractual terms $(M=3.462)$, implying that the vendors did not expect their vendors to go out of the way to help them.

Therefore, ease of access was indeed an important technical consideration in the purchase decision, as organisational buyers indeed expected their buyers to be accessible and available when they need apart from being reliable and efficient.

Table 6.Descriptive Statistics for Ease of Access

\begin{tabular}{lcc}
\hline \multicolumn{1}{c}{ Questions } & Mean & $\begin{array}{c}\text { Std. } \\
\text { Deviation }\end{array}$ \\
\hline $\begin{array}{l}\text { I prefer suppliers who are easily } \\
\text { accessible logistically }\end{array}$ & 3.644 & 1.294 \\
$\begin{array}{l}\text { I prefer suppliers who support their } \\
\text { clients in the time of need }\end{array}$ & 3.591 & 1.753 \\
$\begin{array}{l}\text { I prefer suppliers who are willing to } \\
\text { cooperate beyond contractual } \\
\text { provisions }\end{array}$ & 3.462 & 1.552 \\
$\begin{array}{l}\text { I prefer suppliers who provide } \\
\text { value-added services. }\end{array}$ & 3.629 & 1.572 \\
$\begin{array}{l}\text { I prefer reliable and efficient } \\
\text { suppliers }\end{array}$ & 3.629 & 1.629 \\
$\begin{array}{l}\text { I prefer suppliers who can track and } \\
\text { coordinate online purchases }\end{array}$ & 3.508 & 1.273 \\
$\begin{array}{l}\text { I prefer suppliers whose personnel } \\
\text { are easily accessible in times of } \\
\text { need }\end{array}$ & 3.727 & 1.454 \\
$\begin{array}{l}\text { I appreciate easy access to the top } \\
\text { management of suppliers in cases } \\
\text { of disputes or making strategic } \\
\text { purchase plans }\end{array}$ & 3.644 & 1.585 \\
\hline
\end{tabular}

\section{3. 4. Point of Presence}

Descriptive statistics pertaining to the respondents' perceptions regarding the role of vendors' point of presence, i.e., whether they have multiple branches, locally and globally or not, in the purchase decision process are presented in Table 7. At the outset, organisational buyers were found to have mixed perceptions regarding the importance of the vendors' point of presence, as they agreed with a few questions pertaining to point of presence and remained neutral with regard to the rest.

A majority of the respondents were found to favour suppliers who had the experience of serving a good number of clients in the past, than a new vendor $(M=3$. 742 ) and most of them were already buying from vendors who have a presence in multiple locations $(M=3.621)$. On the contrary, the respondents were neutral with regard to the global presence of their vendors

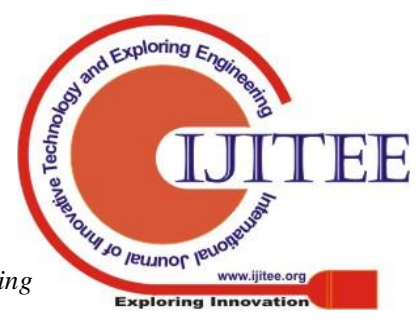


(M=3. 402) and their preference for suppliers with global presence, than local vendors. A clear understanding regarding the organisational buyers' expectations regarding their suppliers' point of presence is obtained here, as it is clear that although buyers expected their vendors to have multiple presence and good experience, they did not expect their suppliers to have a global presence. Therefore, the buying organisations indeed preferred multiple points of presence, but did not bother bout the vendors being global players.

Table 7.Descriptive Statistics for Point of presence of supplier

\begin{tabular}{lcc}
\hline \multicolumn{1}{c}{ Questions } & Mean & $\begin{array}{c}\text { Std. } \\
\text { Deviation }\end{array}$ \\
\hline $\begin{array}{l}\text { My supplier has apresence in } \\
\text { multiple locations }\end{array}$ & 3.621 & 1.199 \\
$\begin{array}{l}\text { My supplier has a global presence } \\
\text { I prefer a supplier with a global }\end{array}$ & 3.402 & 1.023 \\
presence than only local operation & 3.030 & 1.096 \\
$\begin{array}{l}\text { I prefer to buy from a supplier who } \\
\text { has serviced a good number of } \\
\text { customers in the past than a new }\end{array}$ & 3.742 & 1.044 \\
market entrant & & \\
\hline
\end{tabular}

\section{3. 5. Technical Quality}

The descriptive statistics pertaining to the respondents' perceptions regarding the prominence of the technical quality of their vendors and the products to be bought in the purchase decision process are presented in Table 8 . At the outset, organisational buyers were found to attach quite high value to the quality of the vendors and their products as most of them agreed to the questions pertaining to the same.

Most buyers were found to favour vendors who upgrade their telecom network, even for their clients ask for it $(M=3$. 720) and vendors whose networks take less time to recover $(M=3$. 712). The buyers agreed that they prefer suppliers whose network can upgrade faster $(M=3$. 697 ) and their purchase negotiations are mostly done on the basis of product quality $(M=3$. 689). The vendors' preparedness to meet client demands at a short call was favoured by a good number of respondents $(M=3$. 636) and most of them favoured vendors offering products with longer life $(\mathrm{M}=3.621)$. Further, the respondents also preferred vendors who perform according to the service level agreements with regard to 'up' time and response time of the network $(\mathrm{M}=3$. 614) and equally favouredvendors who can design their products according to the clients' requirements and those who can provide network services beyond organisational and geographical boundaries in real-time $(M=3$. 598). Similarly, the organisational buyers were also found to prefer vendors using the latest technology and upgrading constantly $(\mathrm{M}=3$. 568) and those offering complete end-to-end telecom network solutions by themselves $(\mathrm{M}=3$. 553). However, the respondents' took a neutral stand when they were asked if they study the vendors' balance sheets to ascertain their business performance while deciding to purchase from them $(M=3.280)$. Thus, while the organisational buyers indeed expected utmost standards of product quality and adherence to business norms from their vendors, they did not seem to attach much value on whether how vendors are performing.

\section{Table 8.Descriptive statistics for technical quality} attributes of service provider

\begin{tabular}{lcc}
\hline \multicolumn{1}{c}{ Questions } & Mean & $\begin{array}{c}\text { Std. } \\
\text { Deviation }\end{array}$ \\
\hline $\begin{array}{l}\text { I study the balance sheet of the } \\
\text { vendor and select a profitable }\end{array}$ & 3.280 & 0.773 \\
$\begin{array}{l}\text { vendor } \\
\text { My purchase negotiations are }\end{array}$ & 3.689 & 1.306 \\
$\begin{array}{l}\text { largely based on the aspect of } \\
\text { quality }\end{array}$ & & \\
$\begin{array}{l}\text { I prefer suppliers who can design } \\
\text { their products according to our }\end{array}$ & 3.598 & 1.389 \\
$\begin{array}{l}\text { requirements and specifications } \\
\text { I prefer suppliers who upgrade their }\end{array}$ & 3.720 & 1.307 \\
$\begin{array}{l}\text { network well ahead of customer } \\
\text { needs }\end{array}$ & & \\
$\begin{array}{l}\text { I prefer suppliers who offer a short } \\
\text { network recovery time }\end{array}$ & 3.712 & 1.393 \\
$\begin{array}{l}\text { I prefer suppliers who can offer } \\
\text { faster network upgrade ability }\end{array}$ & 3.697 & 1.459 \\
$\begin{array}{l}\text { I prefer suppliers who use latest } \\
\text { technology and keep updating }\end{array}$ & 3.568 & 1.604 \\
$\begin{array}{l}\text { I prefer supplier who has real-time } \\
\text { capability for providing network } \\
\text { services spanning organizational } \\
\text { and geographic boundaries }\end{array}$ & 3.598 & 1.554 \\
$\begin{array}{l}\text { I prefer suppliers offering complete } \\
\text { end-to-end solution on its own }\end{array}$ & 3.553 & 1.429 \\
$\begin{array}{l}\text { I prefer suppliers who adhere to the } \\
\text { service level agreements regarding } \\
\text { the up time and response time }\end{array}$ & 3.614 & 1.648 \\
$\begin{array}{l}\text { Supplier's preparedness to meet our } \\
\text { demand on short notice plays and }\end{array}$ & 3.636 & 1.223 \\
$\begin{array}{l}\text { important role in buying decision } \\
\text { I prefer suppliers offering products } \\
\text { with least perish ability, i.e., longer } \\
\text { life of the products and services }\end{array}$ & 3.621 & 1.249 \\
\hline & & \\
\hline I & & \\
\hline
\end{tabular}

\section{3. 6. Customer Service and Marketing}

Descriptive statistics pertaining to the organisational buyers' perceptions regarding the role of customer service and marketing aspects of the vendor in the purchase decision process are presented in Table 9. Overall, organisational buyers were found to expect higher customer service standards from their vendors, but were not keen on their promotional tactics.

Most buyers emphasised the vendors' ability to deliver better products and services $(M=3$. 720), while deciding to buy from them and a good number of respondents were found to favour vendors who provide good quality as well as customisation services $(M=3$. 269). Similarly, the buyers also favoured vendors who work on keeping their clients increasingly satisfied by providing value added services 
$(\mathrm{M}=3$. 50); however, they were neutral regarding

their preference for vendors who use advertisements and product promotions to gain business $(M=2$. 879). Therefore, while the organisational buyers indeed expected better quality products and customer service from their vendors, they did not seem to bother about suppliers' marketing and promotional efforts while deciding to purchase.

\section{Table 9.Descriptive statistics for customer service and marketing attributes}

\begin{tabular}{|c|c|c|}
\hline Questions & Mean & $\begin{array}{c}\text { Std. } \\
\text { Deviation }\end{array}$ \\
\hline $\begin{array}{l}\text { I prefer suppliers who use } \\
\text { advertisements and promotions to } \\
\text { sensitize and attract customers }\end{array}$ & 2.879 & 0.864 \\
\hline $\begin{array}{l}\text { I decide in favour of suppliers } \\
\text { provider who strive to improve } \\
\text { customer satisfaction through } \\
\text { value-added services }\end{array}$ & 3.500 & 1. 255 \\
\hline $\begin{array}{l}\text { Suppliers should offer better quality } \\
\text { and customization services }\end{array}$ & 3. 629 & 1. 381 \\
\hline $\begin{array}{l}\text { In order to deal with a supplier, I } \\
\text { need to be confident of their } \\
\text { capability to deliver better product } \\
\text { and service }\end{array}$ & 3. 720 & 1. 413 \\
\hline
\end{tabular}

\section{4. Impact of Technical Considerations on $B 2 B$} Purchase Decision

Hypothesis 1; Technical considerations have a significant impact on $\mathrm{B} 2 \mathrm{~B}$ purchase decision.

Linear regression was employed to assess the extent to which technical considerations play a role in the buying organisations' decision to purchase and the results of the same are presented in Tables 10 and 11. The analysis revealed that technical attributes associated with the telecom products and vendors explained about $29 \%$ of the variation occurring in the purchase decisions of buying organisations. This relationship between the independent and dependent variables was statistically significant $(\mathrm{F}=2$. $616, \mathrm{p}>0$. 05). Further, the analysis also implied a fairly moderate, yet, statistically significant correlation between the technical considerations and B2B purchase decision $(\mathrm{r}=0$. 540). Therefore, any unit improvement in the technical attributes of the telecom products will increase the chances of those products being purchased by about $29 \%$.

Further, with regard to the sub-factors of technical attributes, only product price and point of presence of the vendor impact organisational purchase decision significantly, wherein the former exerted a positive influence and the latter had a negative impact. A unit change in product price was found to exert a positive influence by bringing about $\mathrm{B}=0.193$ variations in purchase decision; whereas a unit change in the point of presence of the vendor impacted the purchase decision negatively, by causing $\mathrm{B}=-0.134$ change in the purchase decision. However, the remaining attributes, namely, brand image, ease of access, technical quality and customer service and marketing failed to impact the purchase decision significantly. Thus, while technical attributes overall exerted a significant impact on the purchase decision, all the individual components of technical attributes, except product price and point of presence, failed to affect purchase decisions.

Thus, the first hypothesis $\mathrm{H}_{1}$, which holds that technical considerations have a significant impact on the $\mathrm{B} 2 \mathrm{~B}$ purchase decision, is accepted.

Therefore, pricing and point of presence are the factors that mostly affect the B2B buying decisions and any change in these factors alters the vendors' chances of being selected significantly. However, the beta coefficient value pertaining to the price indicates a positive correlation between prices, which is unusual, as an increase in price should ideally reduce the odds of a vendor selection. An explanation regarding the relationship of purchase decision with price can be drawn from a study by Lambert, Adams and Emmelhainz (1997) who found that product price was not considered important while selecting vendors, as buyers tend to focus on other attributes of the product. These findings were also justified by Abratt (1986) who found that buying firms place emphasis on service quality rather than price and will be ready to pay higher prices for better quality.

Interestingly, the beta coefficient value of point of presence also posits an unusual situation as any increase in point of presence should ideally work in favour of the vendor, but here there is an inverse relationship between point of presence and purchase decision. Crudely, this could mean that the Indian buyer firms tend to prefer organisations which do not have large number ofbranches and any increase in the vendors' points of presence tends to reduce their chances of being selected for purchase. However, there is no research evidence to justify the same and this is one of the contributions of the present study, which needs to be verified with further research.

Further, findings are in contrast to a number of studies that dealt with the importance of price and point of presence in the purchase decision. Important among them is a study by Ho, Xu and Dey (2010) who argued that the geographical location of the vendor and their proximity to the buying firms are paramount for purchase decisions. A similar observation was made by $\mathrm{Ng}$ (2010) in the context of the Taiwanese agriculture sector of Taiwan, who found that the vendors' geographical location exerts a significant impact on purchase decisions as it implies ease of reaching out to the vendor. Further, from a global context, similar findings were obtained by Trent and Monczka (2003) who found that buying firms prefer to buy products from firms with a global presence as it implies better quality. 
Table 10.Model Summary of the Impact of Technical Considerations on B2B Purchase Decision

\begin{tabular}{|c|c|c|c|c|c|c|c|c|}
\hline \multirow[b]{2}{*}{$\mathbf{R}$} & \multirow[b]{2}{*}{$\begin{array}{c}\text { R } \\
\text { Square }\end{array}$} & \multirow[b]{2}{*}{$\begin{array}{c}\text { Adjusted R } \\
\text { Square }\end{array}$} & \multirow{2}{*}{$\begin{array}{c}\text { Std. Error } \\
\text { of the } \\
\text { Estimate }\end{array}$} & \multicolumn{5}{|c|}{ Change Statistics } \\
\hline & & & & R Square Change & F Change & df1 & df2 & $\begin{array}{c}\text { Sig. F } \\
\text { Change }\end{array}$ \\
\hline 540 & 0.292 & 0.136 & 0.441 & 0.058 & 2.616 & 6 & 257 & 0.018 \\
\hline
\end{tabular}

Table 11.Coefficients for the sub factors of technical considerations and purchase decision

\begin{tabular}{|c|c|c|c|c|c|}
\hline & \multicolumn{2}{|c|}{$\begin{array}{l}\text { Unstandardized } \\
\text { Coefficients }\end{array}$} & \multirow{2}{*}{$\begin{array}{c}\text { Standardized } \\
\text { Coefficients } \\
\text { Beta }\end{array}$} & \multirow[b]{2}{*}{$\mathbf{t}$} & \multirow[b]{2}{*}{ Sig. } \\
\hline & B & Std. Error & & & \\
\hline (Constant) & 3.701 & 0.198 & & 18.737 & 0.000 \\
\hline Brand Image & 0.001 & 0.048 & 0.002 & 0.029 & 0.977 \\
\hline Point of presence of supplier & -0.134 & 0.045 & -0.233 & -2.991 & 0.003 \\
\hline Pricing & 0.193 & 0.067 & 0.241 & 2.875 & 0.004 \\
\hline Ease of Access & -0.039 & 0.052 & -0.112 & -0.751 & 0.453 \\
\hline $\begin{array}{l}\text { Technical quality attributes of service } \\
\text { provider }\end{array}$ & 0.082 & 0.064 & 0.196 & 1. 273 & 0.204 \\
\hline $\begin{array}{l}\text { Customer service and marketing } \\
\text { attributes }\end{array}$ & -0.017 & 0.050 & -0.037 & -0.342 & 0.733 \\
\hline
\end{tabular}

\section{5. Interaction Effect of Technical Considerations and Company Size on B2B Purchase Decision}

Univariate analysis was undertaken to measure how technical considerations and company size interact with one another and affect organisational purchase decision and the results of the same are presented in Table 12. A significantly positive interaction effect of technical consideration and company size was found to exist, which in turn affected the final B2B purchase decision $(\mathrm{F}=7.958, \mathrm{p}<0.05)$. However, only two of the six subfactors of technical considerations, i.e., brand image and point of presence of the vendor were found to exert a significant impact on organisational purchase decision along with organisation size, with associatedF values, $F=9.735$ and $F=15.178$ respectively and $p<0.05$. Further, between the two sub-factors, the point of presence of the vendor was found to exert a higher significant impact on the purchase decision along with company size. The rest of the sub-factors, i.e., product price, ease of access, technical quality and customer service and marketing did not seem to have any bearing on the purchase decision along with the size of the organisation. Further, the $\mathrm{R}^{2}$ value implied that company size and technical factors caused about $20 \%\left(R^{2}=0.199\right)$ variation in organisational purchase decision.

Therefore, as the size of the organisation was found to interact significantly with overall technical considerations and in turn exert a significant influence on purchase decisions, the secondhypothesis, $\mathrm{H}_{2}$, which held that technical considerations interact with the size of the buying organization and influence the B2B purchase decision significantly is accepted.

The findings regarding the interactional impact of brand image and size on purchase decisions are in agreement with the observations made by Gomes, Fernandes and Brandão (2014), who observed that organisation size, along with the brand value exerts a significant impact on vendor selection. Similarly, a number of studies have demonstrated the importance of point of presence on purchase decision, for instance, Ho, $\mathrm{Xu}$ and Dey (2010) found that firms with a closer point of presence, i.e., closer proximity with the buyers favour purchase decisions. Similarly, Ng (2010) also opined that as closer geographical location makes reaching out to the vendor simpler, it indeed impacts the purchase decision. However, there is no academic evidence to justify the above and the same can be safely claimed to be the novel finding of the present study.

Table 12.Effect of interaction among size of organization and technical and market factors on purchase decision

\begin{tabular}{|c|c|c|c|c|c|}
\hline Source & $\begin{array}{c}\text { Type III Sum } \\
\text { of Squares }\end{array}$ & df & $\begin{array}{c}\text { Mean } \\
\text { Square }\end{array}$ & $\mathbf{F}$ & Sig. \\
\hline Size of the organization & 0.612 & 2 & 0.306 & 1.788 & 0.169 \\
\hline Brand Image & 1. 666 & 1 & 1. 666 & 9.735 & 0.002 \\
\hline Point of presence of supplier & 2.597 & 1 & 2. 597 & 15. 178 & 0.000 \\
\hline Pricing & 0.504 & 1 & 0.504 & 2.943 & 0.087 \\
\hline Ease of Access & 0.105 & 1 & 0.105 & 0.615 & 0.434 \\
\hline Technical quality attributes of service provider & 0.194 & 1 & 0.194 & 1. 132 & 0.288 \\
\hline Customer service and marketing attributes & 0.439 & 1 & 0.439 & 2. 566 & 0.110 \\
\hline
\end{tabular}




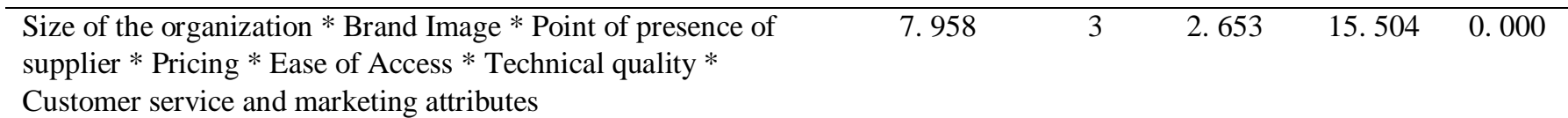

R Squared $=0.199($ Adjusted R Squared $=0.164)$

\section{CONCLUSION}

The present paper intended to gain an in depth understanding regarding the influence of technical factors on $\mathrm{B} 2 \mathrm{~B}$ purchase decisions in the context of the products and services offered by Indian Telecom companies. In order to achieve this, the technical considerations of purchase decision were categorised into six groups, namely brand image, product price, ease of access, point of presence, technical quality and customer service and marketing attributes and the extent to which each of these factors impact the organisational purchase behaviour. The study provided valuable insights with regard to what buyers expect from their suppliers of telecom products and services.

At the outset, descriptive analysis implied that while buyers attached significant value to brand value, they still considered the operational attributes of the product/ service. Further, although firms did not mind higher prices for better quality, they indeed favoured vendors who provided long-term cost reduction services along with their products. Firms attached significant value to easy accessibility of the vendors and while they expected vendors to have multiple branches and prior experience, they were not very particular about the vendors' global presence. Similarly, buyer firms expected their vendors to provide technologically advanced products and quick up gradation and favoured vendors who offered good quality products and services, but were not very keen on the marketing and promotional efforts of the vendors.

Results of statistical analysis revealed that technical considerations indeed exerted a significant impact on the purchase decisions of the buying organisations; however, only product price and point of presence exerted a statistically significant impact on purchase decisions. Further, the findings also implied that the technical attributes interacted significantly with company size and in turn impacted the B2B purchase decisions and among them brand value and point of presence exerted significant interactive influence on purchase decision along with company size. Interestingly, the study found a negative impact of point of presence on purchase decision, which indicates the need to study the extent to which this particular factor affects telecom product purchase decisions. The present study is important in the sense that it contributes to the limited research literature available with regard to organisational telecom products and services buying behaviour of Indian organisations.

\section{REFERENCES}

1. Abratt, R. (1986). Industrial buying in high-tech markets. Industrial Marketing Management, 15(4), 293-298.

2. Azar, A. ,Kahnali, R. A. , \&Taghavi, A. (2010). Relationship between supply chain quality management practices and their effects on organisational performance. Singapore Management Review, 32(1), 45-69.
3. Ballantyne, D. ,\& Aitken, R. (2007). Branding in B2B markets: insights from the service-dominant logic of marketing. Journal of Business \& Industrial Marketing, 22(6), 363-371.

4. Bals, L. , Hartmann, E., \& Ritter, T. (2009). Barriers of purchasing departments' involvement in marketing service procurement. Industrial Marketing Management, 38(8), 892-902.

5. Bendixen, M. ,Bukasa, K. A., \&Abratt, R. (2004). Brand equity in the business-to-business market. Industrial Marketing Management, 33(5), 371-380.'

6. Blombäck, A. ,\&Axelsson, B. (2007). The role of corporate brand image in the selection of new subcontractors. Journal of Business \& Industrial Marketing, 22(6), 418-430.

7. Bolton, R. N. , Lemon, K. N. , \&Verhoef, P. C. (2008). Expanding business-to-business customer relationships: Modeling the customer's upgrade decision. Journal of Marketing, 72(1), 46-64.

8. Brown, B. P. ,Bellenger, D. N. , \& Johnston, W. J. (2007). The implications of business-to-business and consumer market differences for B2B branding strategy. Journal of business market management, 1(3), 209-230.

9. Calvi, R. , Le Dain, M. A. , Fendt, T. C. , \& Herrmann, C. J. (2010). Supplier selection for strategic supplier development.

10. Chiu, H. F., Lee, T. R. , \& Kao, C. K. (2015). The Key Factors of Selecting Electronics Manufacturing Service Suppliers-an Example of Company $\mathrm{U}$ in Taiwan. Management and Production Engineering Review, 6(4), 4-14.

11. Chowdary, T. H. (1998). Politics and economics of telecom liberalization in India. Telecommunications Policy, 22(1), 9-22.

12. Dean, A. ,\&Terziovski, M. (2001). Quality practices and customer/supplier management in Australian service organizations. Total Quality Management, 12(5), 611-621.

13. Ebitu, E. T. ,Essien, E. E. , \& Basil, G. (2012). Price-quality Dimensions of Organizational Buying Behaviour in Cross River State, Nigeria. International Journal of Marketing Studies, 4(4), 78.

14. Eid, R. ,Trueman, M. , \&Moneim Ahmed, A. (2002). A crossindustry review of $\mathrm{B} 2 \mathrm{~B}$ critical success factors. Internet Research, 12(2), 110-123.

15. French, J. and Raven, B. (1959). The Bases of Social Power. In Studies in Social Power, D. Cartwright, Ed. , pp. 150-167. Ann Arbor, MI: Institute for Social Research.

16. Gartnell, A. ,Freij, M. , \&Svensson, A. (2013). Brands in businessto-business: A qualitative research of brand influence in organizational buying behavior.

17. Gomes, M. ,Fernandes, T. , \&Brandão, A. (2014). The Role of Branding in a B2B Purchasing Context. In 4th Conference of the International Network of Business and Management Journals (INBAM).

18. Gonzalez, M. E. , Quesada, G. , \& Mora Monge, C. A. (2004) Determining the importance of the supplier selection process in manufacturing: a case study. International Journal of Physical Distribution \& Logistics Management, 34(6), 492-504.

19. Haußmann, A. L. (2016). The impact of brand images on the purchasing behavior of business-to-business market participants (Doctoral dissertation, university of latvia).

20. Ho, W. ,Xu, X. , \&Dey, P. K. (2010). Multi-criteria decision making approaches for supplier evaluation and selection: A literature review. European Journal of Operational Research, 202(1), 16-24.

21. IBEF (2017). Indian Telecom Industry Analysis. Retreived from https://www. ibef. org/industry/indian-telecommunicationsindustry-analysis-presentation.

22. Jobber, D. , 2001, Principles \& Practice of Marketing, 3rd edition, McGraw-Hill, Berkshire

23. Kahraman, C. ,Cebeci, U. , \&Ulukan, Z. (2003). Multi-criteria supplier selection using fuzzy AHP. Logistics information management, 16(6), 382-394.

24. Kotler, P. ,\& Armstrong, G. (2010). Principles of marketing. Pearson education.

25. Kotler, P. ,\&Pfoertsch, W. (2007). Being known or being one of many: the need for brand management for businessto-business \begin{tabular}{ll} 
to-business & \multicolumn{1}{c}{ (B2B) } \\
companies. Journal of
\end{tabular} 
Business \& Industrial Marketing, 22(6), 357-362.

26. Koufteros, X. , Vickery, S. K. , \&Dröge, C. (2012). The effects of strategic supplier selection on buyer competitive performance in matched domains: does supplier integration mediate the relationships?.Journal of Supply Chain Management, 48(2), 93115.

27. Krause, D. R. ,Pagell, M. , \&Curkovic, S. (2001). Toward a measure of competitive priorities for purchasing. Journal of Operations Management, 19(4), 497-512.

28. Kuei, C. H. ,Madu, C. N. , \& Lin, C. (2001). The relationship between supply chain quality management practices and organizational performance. International Journal of Quality \& Reliability Management, 18(8), 864-872.

29. Lai, K. H. , Cheng, T. E. , \&Yeung, A. C. (2004). An empirical taxonomy for logistics service providers. Maritime Economics \& Logistics, 6(3), 199-219.

30. Lambert, D. M. , Adams, R. J. , \&Emmelhainz, M. A. (1997). Supplier selection criteria in the healthcare industry: A comparison of importance and performace. Journal of Supply Chain Management, 33(4), 16-22.

31. Lambert, D. R. (1981). Price as a quality cue in industrial buying. Journal of the Academy of Marketing Science, 9(3), 227-238.

32. Lehmann, D. R. ,\&O'shaughnessy, J. (1974). Difference in attribute importance for different industrial products. The Journal of Marketing, 36-42.

33. Luthra, S. ,Govindan, K. , Kannan, D. , Mangla, S. K. , \&Garg, C. P. (2017). An integrated framework for sustainable supplier selection and evaluation in supply chains. Journal of Cleaner Production, 140, 1686-1698.

34. Mishra, A. K. ,\&Rao, G. (2015). Analysing Anti-competitive Behaviour: The Case for Indian Telecom Industry. Science, Technology and Society, 20(1), 21-43.

35. Morgan, F. ,Deeter-Schmelz, D. , \&Moberg, C. R. (2007). Branding implications of partner firm-focal firm relationships in business-to-business service networks. Journal of Business \& Industrial Marketing, 22(6), 372-382.

36. Mudambi, S. (2002). Branding importance in business-to-business markets: Three buyer clusters. Industrial Marketing Management, 31(6), 525-533.

37. Mudambi, S. M., Doyle, P. , \& Wong, V. (1997). An exploration of branding in industrial markets. Industrial Marketing Management, 26(5), 433-446.

38. Mwikali, R. ,\&Kavale, S. (2012). Factors affecting the selection of optimal suppliers in procurement management. International Journal of Humanities and Social Science, 2(14), 189-193.

39. Nair, A. Jayaram, J. , \& Das, A. (2015). Strategic purchasing participation, supplier selection, supplier evaluation and purchasing performance. International Journal of Production Research, 53(20), 6263-6278.

40. Ng, E. (2010). Understanding B2B supplier selection relationships: the case of Taiwan agribusinesses. Journal of Business-to-Business Marketing, 17(2), 149-172.

41. Nurmi, S. (2012). Business to business buying behaviour: An analysis and sales strategy for Aalund Customer Dialogue.

42. Pride, William M. \& Ferrell, O. C. .2009, Foundations of Marketing. 4th edition. Cengage learning. 544.

43. Rahim, A. S. (2013). Supplier selection in the Malaysian telecommunications industry (Doctoral dissertation, Brunel University Brunel Business School PhD Theses).

44. Robinson, P. J. , Farris, C. W. , \& Wind, Y. (1967). Industrial Buying Behavior.

45. Shah, N. (2008). Critically analyze the customer preference and satisfaction measurement in Indian Telecom Industry. Retrieved on January 2011 from http://www. slideshare. net/guest377d84/telecomsector-thesis.

46. Shaw, J. ,Giglierano, J. , \&Kallis, J. (1989). Marketing complex technical products: The importance of intangible attributes. Industrial Marketing Management, 18(1), 45-53.

47. Travis, P. (2015). Branding \& targeted marketing for $b 2 b$ smes in the current market: a case study with consulting firm $\mathrm{x}$.

48. Trent, R. J. ,\&Monczka, R. M. (2002). Pursuing competitive advantage through integrated global sourcing. The Academy of Management Executive, 16(2), 66-80.

49. Trent, R. J. ,\&Monczka, R. M. (2003). International Purchasing and Global Sourcing-What are the Differences?.Journal of Supply Chain Management, 39(3), 26-36.

50. Walley, K. ,Custance, P. , Taylor, S. , Lindgreen, A. , \&Hingley, M. (2007). The importance of brand in the industrial purchase decision: a case study of the UK tractor market. Journal of Business \& Industrial Marketing, 22(6), 383-393. 